\title{
Youth homicide: a study of homicide predictor factors in adolescent offenders in custody in the south of Brazil
}

\author{
Homicídio juvenil: fatores preditores em adolescentes privados \\ de liberdade no sul do Brasil
}

\begin{abstract}
Manuela Teixeira Schorr, ${ }^{1,2}$ (D) Renata Ramos Reichelt, ${ }^{1,2}$ Lucas Primo de Carvalho Alves, ${ }^{1,2}$ Bibiana de Borba Telles, ${ }^{3}$ Luana Strapazzon, ${ }^{1,2}$ Lisieux Elaine de Borba Telles ${ }^{1,2}$
\end{abstract}

\begin{abstract}
Objectives: To assess the sociodemographic, psychiatric and criminal profile of adolescent offenders complying with temporary custody for homicide/homicide attempt and to compare it to that of the population of adolescents in custody for other crimes.

Methods: This cross-sectional study was based on the review of the medical records of 74 juvenile offenders in temporary custody at socioeducational agency Fundação de Atendimento Sócio-Educativo do Rio Grande do Sul. For the analysis, variables that presented $\mathrm{p}<0.2$ were included in multivariate adjustment through logistic regression.

Results: The sample comprised males only, mostly with white skin color ( 55.6 vs. $57.9 \%$ for homicidal and non-homicidal, respectively) and with a high prevalence of school failure ( 77.8 vs. $91.2 \%)$. There was a high prevalence of family history of delinquency ( 88 vs. $81 \%$ ). Only years of study and belonging or not to a criminal organization remained statistically significant in the multivariate model.

Conclusion: The results show that having fewer years of study and denying belonging to a criminal organization are predictive factors of homicidal behavior in adolescent offenders (both with statistical relevance). The other variables were not statistically significant for this outcome. The present study may serve as a basis for further research, which may improve our understanding of risk factors for juvenile homicide.
\end{abstract}

Keywords: Conduct disorder, juvenile delinquency, homicide, violence, adolescent.

\section{Resumo}

Objetivos: Avaliar o perfil sociodemográfico, psiquiátrico e criminal de adolescentes infratores que cumprem internação provisória por homicídio ou tentativa de homicídio e comparálos aos adolescentes privados de liberdade por outros atos infracionais.

Métodos: Este estudo transversal baseou-se na revisão dos prontuários médicos de 74 adolescentes infratores em internação provisória na Fundação de Atendimento Sócio-Educativo do Rio Grande do Sul. Para a análise, variáveis que apresentaram $p<0,2$ foram incluídas no ajuste multivariado por meio de regressão logística.

Resultados: A amostra foi composta apenas por homens, a maioria de pele branca $(55,6$ versus $57,9 \%$ para homicidas e não-homicidas, respectivamente) e com alta prevalência de reprovações escolares $(77,8$ vs. $91,2 \%)$. Houve alta prevalência de antecedentes familiares de delinquência (88 versus $81 \%$ ). Apenas anos de estudo e pertencimento ou não a uma organização criminosa permaneceram estatisticamente significantes no modelo multivariado.

Conclusão: Os resultados mostram que ter menos anos de estudo e negar pertencer a uma organização criminosa foram fatores preditivos de comportamento homicida em adolescentes infratores (ambos com relevância estatística). As demais variáveis não foram estatisticamente significativas para esse desfecho. 0 presente estudo pode servir como base para futuras pesquisas, 0 que pode melhorar nossa compreensão dos fatores de risco para o homicídio juvenil.

Descritores: Transtorno de conduta, delinquência juvenil, homicídio, violência, adolescente.

\footnotetext{
${ }^{1}$ Hospital de Clínicas de Porto Alegre (HCPA), Porto Alegre, RS, Brazil. ${ }^{2}$ Universidade Federal do Rio Grande do Sul (UFRGS), Porto Alegre, RS, Brazil. ${ }^{3}$ Universidade Federal de Ciências da Saúde de Porto Alegre (UFCSPA), Porto Alegre, RS, Brazil.

Submitted Oct 11 2018, accepted for publication Jan 132019.

Suggested citation: Schorr MT, Reichelt RR, Alves LPC, Telles BB, Strapazzon L, Telles LEB. Youth homicide: a study of homicide predictor factors in adolescent offenders in custody in the south of Brazil. Trends Psychiatry Psychother. 2019;41(3):292-296. http://dx.doi.org/10.1590/2237-6089-2018-0076
} 


\section{Introduction}

In Brazil, adolescents who commit an offense are promptly brought to a juvenile court and are subject to the application of socioeducational activities during custody and probation, in accordance with the Child and Adolescent Statute (Estatuto da Criança e do Adolescente, enacted through Law 8069/90). ${ }^{1}$ Article 122 of the Statute establishes that the penalties applicable to adolescents include warning, reparation of damage, community service, probation, conditional release and custody. ${ }^{1,2}$ In southern Brazil, The Fundação de Atendimento Socio-Educativo do Rio Grande do Sul (FASE-RS) is the agency that applies socioeducational activities of custody and conditional release to adolescents who respond judicially for an offense.

The number of adolescents involved in offenses and problems with the law in Brazil has been growing every year. ${ }^{3,4}$ As with delinquency, homicides committed by young people have also increased in recent years.

Several studies have been designed to study the profile of the young killer as well as the risk factors for such conduct. Córdoba et al. demonstrated that risk factors included few years of schooling and school failure (odds ratio $[O R]=2.3$ ), absence of one of the parents ( $O R=14.3$ for the mother), conduct disorder $(O R=13)$, and alcohol dependence. ${ }^{4}$ Other reported risk factors for homicidal conduct in adolescents include the use of weapons ( $O R=55)$ and having one of the parents imprisoned $(O R=4)$.

A study conducted in Massachusetts aimed to compare a group of violent adolescents who committed homicide to violent adolescents who had not committed such an offense. The authors assessed 33 adolescents imprisoned for homicide compared to 38 adolescents imprisoned in the same institution for violent crime other than homicide. The motivations were diverse: $29 \%$ of homicides occurred as a result of crimes and $20.8 \%$ were motivated by retaliation. There was no statistically significant difference between the groups regarding demographic variables, the presence of parental crime or early experiences of parental death or divorce. ${ }^{5}$

Therefore, the objectives of the present study were to assess the sociodemographic, psychiatric and criminal profile of adolescent offenders complying with temporary custody for homicide/homicide attempt and to compare it to that of the population of adolescents in temporary custody for other crimes.

\section{Methodology}

\section{Study design and setting}

This was a cross-sectional census study involving juvenile offenders in temporary custody. It was carried out at Centro de Internação Provisória Carlos Santos, at FASE-RS, which is the only facility available to treat adolescent male offenders in the state of Rio Grande do Sul, southern Brazil.

\section{Participants}

All the adolescents admitted to the unit in July 2017 were included in the study, to a total of $74(n=74)$. Of these, 18 were in custody for homicide or attempted murder, which was the target population in the present study.

\section{Procedure}

Data available on the medical records of the first psychiatric evaluation of the adolescents were reviewed. All the adolescents admitted during the study period underwent the institution's routine initial evaluation, followed by an internal admission protocol. Diagnoses were made based on clinical assessment, according to criteria from the Diagnostic and Statistical Manual of Mental Disorders, 5th edition (DSM-5). The initial evaluation covered sociodemographic, criminal and psychiatric characteristics, according to information provided by the adolescents. Adolescents who needed treatment as per the psychiatrist's evaluation received regular care according to individual needs. These data, however, were not used in the present study.

\section{Ethical approval}

The project was approved by the research ethics committees of Hospital de Clínicas de Porto Alegre (CAAE 81915317.7.0000.5327) and FASE-RS.

\section{Statistical method}

Individuals were divided into two groups: 1) those who committed homicide offenses; and 2) those who committed other types of offenses. Continuous variables were described as medians and interquartile ranges, as they did not meet the normality assumptions according to the KolmogorovSmirnov test. Univariate logistic regressions were used to evaluate the impact of demographic variables between the groups. Variables showing $p \leq 0.2$ were included in multivariate adjustment through logistic regression. The final model was adjusted using the backward selection method. 


\section{Results}

The sample comprised male adolescents only. The majority of them had white skin color (55.6 vs. $57.9 \%$ for the homicidal and non-homicidal offenders, respectively), followed by brown ( 27.8 vs. $24.6 \%$ ) and black (16.7 vs. $17,5 \%)$. There was a high prevalence of school failure (77.8 vs. $91.2 \%$ ) and evasion (77.8 vs. $73.7 \%)$, but these latter findings were not statistically significant.

The majority of adolescents had a family history of delinquency ( 88 vs. $81 \%$ ), and the prevalence of a murdered relative was $17.6 \%$ in the homicidal group vs. $6.9 \%$ in the non-homicidal one. Finally, chemical dependence in relatives was present in more than $60 \%$ of the cases in both groups (64.7 vs. $62 \%$ )

Regarding the offenders' profile, $38.9 \%$ of the adolescents in the homicidal group had been admitted to FASE-RS previously, at a mean of 2.5 previous detentions; $55.6 \%$ had received some socioeducational punishment in the past, all of which corresponded to probation and/or community services. None of the adolescents in the homicidal group had completed temporary custody (with or without external activity) in the past. In the non-homicidal group, in turn, $42.1 \%$ reported previous admissions to the institution, at a mean of 1.5 times; $49.1 \%$ had received some sort of socioeducational punishment, of which $71.4 \%$ corresponded to probation or community services and $14.3 \%$ to temporary custody; only one adolescent was detained without external activities. Also, 59.6\% of the non-homicidal offenders reported having previously been to the state's specialized child and adolescent police station (Departamento Estadual da Criança e do Adolescente $[\mathrm{DECA}])$.

Table 1 presents the demographic characteristics of the two groups and the respective p-values calculated through logistic regression.

Only the variables years of study and belonging to a criminal organization remained statistically significant in the multivariate model. Table 2 shows the OR of the adjusted model.

Conduct problems among adolescents were investigated in the initial evaluation, based on selfreport, or observed behavior during detention. Data referring to the prevalence of conduct disorder are shown in Table 1 . The prevalence of deviant behavior reported by the adolescents or observed in the unit, however, was much higher than the prevalence of conduct disorder: $88.9 \%$ of the subjects in the homicidal group and $78.9 \%$ in the non-homicidal one had a recurrent history of aggression to people and animals. In the homicidal group, $66.7 \%$ had a history of serious violation of rules, while in the non-homicidal

Table 1 - Demographic, clinical and offending characteristics of individuals with and without homicidal conduct

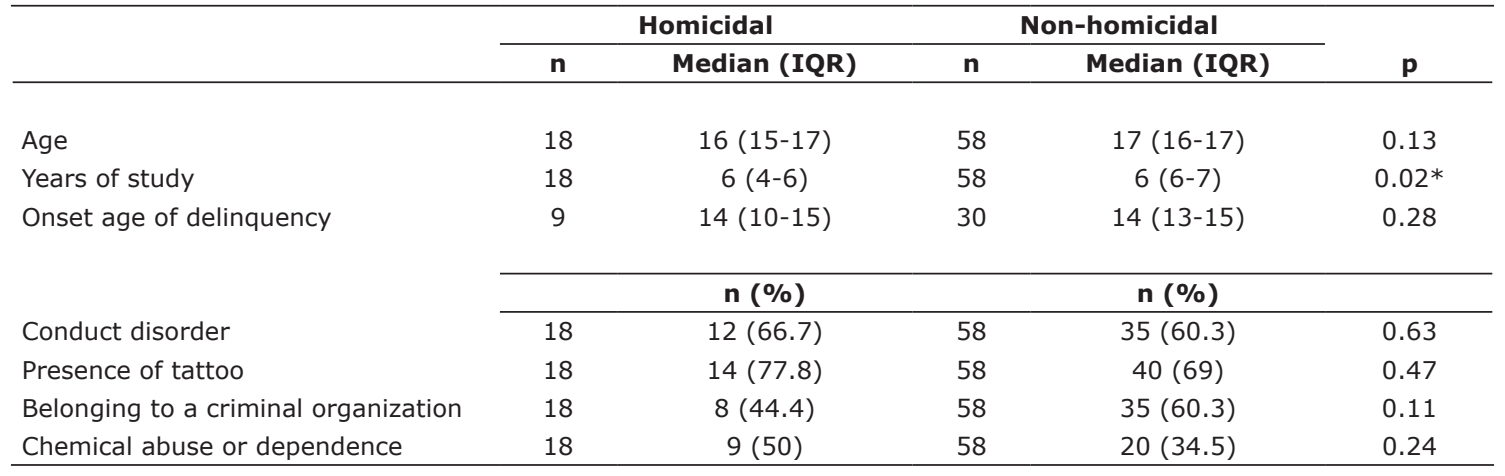

IQR $=$ interquartile range.

$* \mathrm{p}<0.05$.

Table 2 - Multivariate analysis of predictors for homicidal conduct

\begin{tabular}{lcc}
\hline Predictor & OR (95\%CI) & P \\
\hline Years of study & $0.63(0.44-0.9)$ & $0.012^{*}$ \\
Belonging to a criminal organization & $0.31(0.09-1)$ & $0.05^{*}$ \\
\hline OR $(95 \% \mathrm{CI})=$ odds ratio $(95 \%$ confidence interval). & &
\end{tabular}

OR $(95 \% \mathrm{CI})=$ odds ratio $(95 \%$ confidence interval $)$.
$* p<0.05$.

294 - Trends Psychiatry Psychother. 2019;41(3) 
group, this prevalence was $57.9 \%$. History of falsehood or theft was present in $22.2 \%$ of the adolescents in the homicidal group and in $43.9 \%$ in the non-homicidal group. Finally, history of property destruction was present in $22.2 \%$ and $36.8 \%$ of the adolescents in each group, respectively. It is worth mentioning that these data are subject to information bias.

\section{Discussion}

The results of this study showed that having fewer years of study and denying belonging to a criminal organization were predictive factors of homicidal behavior in the adolescents of the present sample in conflict with the law. These two variables showed statistical relevance, whereas the other variables assessed were not statistically significant for the outcome.

Regarding schooling, literature data are controversial: DiCataldo \& Everett did not find significant differences in schooling when comparing homicidal adolescents with violent non-homicidal delinquents in a sample of 71 adolescent offenders. ${ }^{5}$ Baglivio et al., in a prospective study of 9,072 adolescent offenders, analyzed predictive factors for future homicide or attempted homicide in youth deprived of their liberty before age 12 and concluded that school variables (conduct, performance), mental health and age upon first incarceration were all not able to predict homicide in the future. Other findings from that study were that adolescents living with parents/guardians who were mentally ill had a 7.4 times greater chance of being arrested for homicide in the future, and that both selfmutilating behavior and high anger feelings were shown to be predictor factors for this outcome. ${ }^{6}$ Finally, the systematic review conducted by Gerard et al. included 16 articles and identified fewer years of schooling as one of the most robust risk factors for homicidal behavior in young offenders, a finding that is in agreement with the one found in the present study. ${ }^{7}$

Belonging to a criminal organization has been shown to be a risk factor for homicidal conduct in several studies in the literature. Comparing homicidal adolescents with controls, Zagar et al. found that belonging to a criminal organization was a predictor for homicide, with an OR $=4.14 .^{8}$ Busch et al. also found this association to be significant, with $41 \%$ of homicide offenders belonging to a faction, vs. $14 \%$ among nonviolent delinquents. ${ }^{9}$ Córdoba et al., in a study conducted in Colombia, assessed 83 domestic homicidal adolescents, and gang membership was shown to be a risk factor for homicidal conduct, with an OR $=36.99$. The systematic review conducted by Gerard et al. also found that participation in a gang was more prevalent in the homicidal group. ${ }^{7}$

Some other studies, however, did not confirm such association. Loeber et al. failed to find statistically significant differences when it came to belonging to a criminal organization in the comparison between homicidal and non-homicidal violent adolescents. In that study, homicide offenders were more likely to be diagnosed with conduct disorder and to have easy access to a weapon. ${ }^{10}$ In the present study, denying belonging to a criminal organization was associated with homicidal conduct, a fact that should be better explored in future studies.

The high number of delinquents among the family members of adolescents in both groups may be an indicator of the functioning of these families, which in their vast majority have at least one additional family member also involved in crime. These data are in agreement with the literature, which points out to parental delinquency as a risk factor. ${ }^{7,9,11}$

Understanding the risk factors that lead adolescent offenders to commit homicide may help identify those most likely to commit the crime. However, these data should be carefully analyzed because of the heterogeneity of characteristics of homicidal adolescents.

The main limitation of the present study was the small number of participants. Another limitation was the absence of female adolescents in the study, a population that may present quite different characteristics from those here studied and therefore deserves to be analyzed in future studies. Finally, the fact that the data obtained were based on the self-report of adolescents may represent another limitation (information bias). Still, we believe the present study may serve as a basis for further research, which may improve our understanding of risk factors for juvenile homicide.

\section{Disclosure}

No conflicts of interest declared concerning the publication of this article.

\section{References}

1. Brasil. Lei no 8.069, de 13 de julho de 1990. Estatuto da Criança e do Adolescente. Brasília: Casa Civil; 1990. http://www.planalto. gov.br/ccivil_03/leis//8069.htm

2. Foppa GM. Adolescente egresso da FASE: estudo de caso sobre Programa RS Socioeducativo [dissertation]. Porto Alegre: Pontifícia Universidade Católica Rio Grande do Sul; 2010.

3. Macedo VG. Características psicossociais e de personalidade de adolescentes infratores em cumprimento de medida socioeducativa [dissertation]. São Bernardo do Campo: Universidade Metodista de São Paulo; 2016. 
4. Córdoba FE. Riesgo para cometer homicídio em jóvenes bogotanos [thesis]. Bogotá: Universidad Nacional de La Plata; 2006.

5. DiCataldo $F$, Everett M. Distinguishing juvenile homicide from violent juvenile offending. Int J Offender Ther Comp Criminol. 2008;52:158-74.

6. Baglivio MT, Wolff KT. Prospective prediction of juvenile homicide/ attempted homicide among early-onset juvenile offenders. Int J Environ Res Public Health. 2017;14:E197.

7. Gerard FG, Jackson V, Chou S, Whitfield KC, Browne KD. An exploration of the current knowledge on young people who kill: $A$ systematic review. Aggress Violent Behav. 2014;19:559-71.

8. Zagar RJ, Grove WM, Busch KG, Hughes JR. Looking forward and backward in records for risks among homicidal youth. Psychol Rep. 2009;104:103-27.

9. Bush KG, Zagar R, Hughes JR, Arbit J, Bussell RE. Adolescents who kill. J Clin Psychol. 1990;46:472-85.
10. Loeber R, Pardini D, Homish DL, Wei EH, Crawford AM, Farrington $\mathrm{DP}$, et al. The prediction of violence and homicide in young men. J Consult Clin Psychol. 2005;73:1074-88.

11. Vries AM, Liem M. Recidivism of juvenile homicide offenders. Behav Sci Law. 2011;29:483-98.

\section{Correspondence:}

Manuela Teixeira Schorr

Av. Princesa Isabel, 1155/905, Bairro Santana

90620-001 - Porto Alegre, RS - Brazil

Tel.: +55 (51) 993878595

E-mail: mtschorr@hotmail.com 